\title{
Águas subterrâneas e poços tubulares profundos
}

\author{
Editado por Válter Galdiano Gonçalves e Carlos Eduardo Quaglia Giampá
}

E ncontrar, no mercado brasileiro, livros editados em português sobre Hidrogeologia não é muito usual, como afirma o Professor Doutor Uriel Duarte na apresentação do livro. No presente caso, a edição comentada não só preenche a falta mencionada como é um excelente livro para hidrogeólogos, geólogos, engenheiros civis, estudantes e técnicos que trabalham na área de perfuração de poços ou profissionais que gerenciam sistemas de produção de água com captação por meio de poços profundos. Com 14 capítulos e 483 páginas, é possível encontrar todos os temas, ensinamentos e experiências práticas sobre águas subterrâneas e poços profundos em linguagem clara, objetiva e acessível. A publicação contou com a participação de vários profissionais, especialistas e sócios da Associação Brasileira de Águas Subterrâneas (ABAS), os quais conseguiram compartilhar seus conhecimentos em textos sequenciados cobrindo toda a área de águas subterrâneas. Assim, 18 profissionais aplicaram sua experiência sobre perfuração de poços profundos escrevendo os capítulos: "I - Águas subterrâneas": conceitos gerais sobre a origem da água subterrânea e da função dos aquíferos; aspectos geológicos básicos, perfis hidrogeológicos e vantagens de seu uso; mapas hidrogeológicos e importância da gestão de recursos hídricos integrado à gestão ambiental; "II - Elementos de hidrologia de superfície": voltado para a hidrologia com avaliação de bacias hidrográficas, medições de vazão, instrumental para coleta de dados, elaboração de curva chave, fluxogramas, hidrogramas e curvas de depleção; "III - Elementos de hidrologia subterrânea": texto com conceitos gerais sobre hidrogeologia, tipos

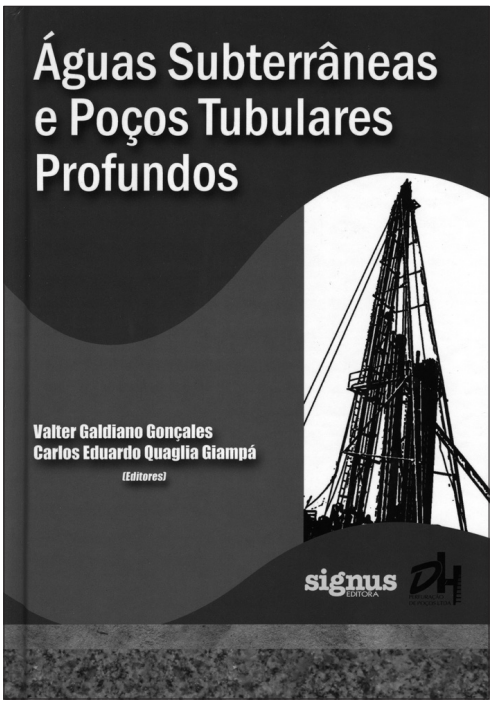
de aquíferos, energia de fluxos subterrâneos, parâmetros hidrodinâmicos de aquíferos, testes de produção e de aquíferos, contendo orientações que não são comuns em livros sobre perfuração de poços; "IV - Qualidade da água": após a conceituação geral, este capítulo trata dos processos geoquímicos e bioquímicos presentes nas águas naturais, apresentando as características químicas das águas subterrâneas, sua análise química, os resultados e a caracterização das águas subterrâneas como importante dado para os operadores e usuários de poços; "V - Prospecção geofísica": é um capítulo que auxilia diretamente os gestores de sistemas de abastecimento de água, na medida em que traz informações técnicas sobre a importância de se estudar a geologia com métodos decorrentes da física, para melhor identificação de locais onde pode haver água subterrânea; "VI - Locação de poços": relevante contribuição pode ser obtida com este texto, no qual se conjugam a experiência prática e os conhecimentos dos fatores e da realidade geológica local para definição dos locais onde se pode encontrar água subterrânea para exploração racional e econômica; "VII - Projeto de poços": fornecer os critérios básicos e conceitos utilizados na elaboração de um projeto para implantação de poços é o objetivo deste capítulo, detentor de um roteiro que facilita o trabalho de hidrogeólogos e analistas de projetos; "VIII - Métodos de perfuração, completação e desenvolvimento de poços tubulares": esse texto demonstra que, para se ter sucesso no projetado, deve-se utilizar o método de perfuração mais adequado e com equipamentos bem dimensionados, e que a operação de perfuração seja gerenciada para que a completação e o desenvolvimento sejam realizados levando a máxima eficiência na exploração da água subterrânea; "IX - Perfilagem de poços": capítulo destinado ao método da perfilagem geofísica para reconstituição do perfil litológico e assentamento de tubos de filtros. Apresenta os princípios básicos, ambientes, formatos e apresentação de perfis, bem como sua interpretação, além de fornecer conhecimentos teóricos sobre a fundamentação técnica da perfilagem; "X - Hidráulica de aquíferos e eficiência de poços": voltado para a interpretação de testes de aquífero e de produção, apresenta todas as equações básicas do regime de equilíbrio e do transitório, fala das perdas de carga nos testes de bombeamento e da elaboração da curva característica do poço; "XI - Conjuntos de bombeamento": não trata apenas do dimensionamento de bombas, motores e quadros de comando; indica problemas a serem analisados durante a operação e faz recomendações importantes para a manutenção eficiente; "XII - Operação e manutenção de poços tubulares": fornece um roteiro prático de procedimentos para a gestão da operação e a manutenção de poços tubulares, tanto nas fases preventivas quanto corretivas; "XIII - Preservação de águas subterrâneas": é um capítulo inovador por tratar, em um livro de caráter técnico-operacional, das questões importantes relativas à interface ambiental com a gestão do uso de águas subterrâneas e a operação de poços tubulares em escala empresarial; "XIV - Gerenciamento de recursos hídricos": traz uma coletânea de informações sobre aspectos institucionais, leis e sistemas de gestão. Os anexos complementam os textos com links, formulários e quadros.

Este livro, enfim, quando se considera a importância da água subterrânea para o abastecimento público e uso industrial em um país que ainda não consolidou as boas práticas da gestão de recursos hídricos, é um instrumento relevante para a gestão eficiente de sistemas de produção de água com poços tubulares. O mesmo pode ser encontrado na DH Perfuração de Poços Ltda., na ABAS ou na SIGNUS Editora.

\section{Comentário elaborado por Álvaro José Menezes da Costa Coordenador da coluna Livros: Cícero Onofre de Andrade Neto}

A sessão "Livros", que a cada edição traz resumos comentados sobre livros de interesse na área, tem como principal objetivo permitir que o leitor, de forma rápida, se atualize e conheça o que há disponível no mercado editorial. As contribuições deverão ser encaminhadas para: resa@abes-dn.org.br 